\title{
Investigation of Natural Radioactivity Levels and Evaluation of Radiation Hazards in Residential-Area Soil Near a Ras Tanura Refinery, Saudi Arbia
}

\author{
Fatimh Alshahri ${ }^{\text {* }}$, A. El-Taher ${ }^{2}$ \\ ${ }^{1}$ Department of Physics, College of Science, Imam Abdulrahman Bin Faisal University, Dammam, Saudi Arabia \\ ${ }^{2}$ Physics Department, Faculty of Science, Al-Azhar University, Assuit, Egypt
}

Received: 29 May 2017

Accepted: 18 January 2018

\begin{abstract}
One of the oldest oil refineries in the Middle East is located south of Ras Tanura in eastern Saudi Arabia, Arabian Gulf. Naturally occurring radionuclides may be associated with the extraction processes of oil and gas. Therefore, the activities concentrations of ${ }^{238} \mathrm{U},{ }^{226} \mathrm{Ra},{ }^{232} \mathrm{Th},{ }^{40} \mathrm{~K}$, and ${ }^{137} \mathrm{Cs}$ in soil samples near Ras Tanura refinery were measured using the gamma ray spectrometric technique. The mean activity concentrations of the radionuclides ${ }^{238} \mathrm{U},{ }^{226} \mathrm{Ra},{ }^{232} \mathrm{Th},{ }^{40} \mathrm{~K}$, and ${ }^{137} \mathrm{Cs}$ were $39.0 \pm 4.8 \mathrm{~Bq} / \mathrm{kg}, 23.2 \pm 1.4 \mathrm{~Bq} / \mathrm{kg}, 7.73 \pm 1.2 \mathrm{~Bq} / \mathrm{kg}, 278 \pm 9.8 \mathrm{~Bq} / \mathrm{kg}$, and $1.42 \pm 0.5 \mathrm{~Bq} / \mathrm{kg}$, respectively. Radiation hazard indices were calculated to evaluate the radiological risk for the public and environment. The results show that the mean values of radium equivalent activity $\left(\mathrm{Ra}_{\mathrm{eq}}\right)$ and gamma absorbed dose rate (D) in air, annual effective dose equivalent (E), and external radiation hazard indices for analyzed samples were lower than the recommended limit by the United Nations Scientific Committee on the Effect of Atomic Radiation. This study is the first to evaluate the radiological impacts in the investigation area. Accordingly, the present study could be considered a baseline for natural radioactivity levels in soil near a refinery area in Ras Tanura.
\end{abstract}

Keywords: soil, radiological hazards, natural radioactivity, Ras Tanura Refinery, Saudi Arabia

\section{Introduction}

The naturally occurring radionuclides present in soil, rocks, and water are not uniformly distributed all over the world, and depend primarily on geological and geographical conditions. Terrestrial gamma rays derive

*e-mail: faalshehri@iau.edu.sa

essentially from ${ }^{40} \mathrm{~K}$ and the radio nuclides belong to ${ }^{238} \mathrm{U}$ and ${ }^{232} \mathrm{Th}$ series that are present in the earth's crust. Apart from these natural sources, modern scientific and technological activities also contribute to radiation levels in the environment [1-2]: ${ }^{137} \mathrm{Cs}$ is regarded as the most important constituent of the worldwide radioactive fallout. In the case of an accidental release of fission products from a nuclear power plant, cesium isotopes are especially significant due to their volatility and large inventory that builds up in the reactor over time. 
Therefore, measuring ${ }^{137} \mathrm{Cs}$ levels in soil is also necessary in the environment as such data would serve as baseline data. Its presence in soil would be an indicator that the area in question might have received some fallout radioactivity in the past [3].

Radioactive materials that occur naturally (NORM) and expose people to radiation occurring widely. NORM is an acronym for naturally occurring radioactive material, which includes long-lived radioactive elements (e.g., uranium, thorium, and potassium) found in the environment [4]. NORM wastes concentrate and accumulate in tubing and surface equipment in the form of scale and sludge [5]. In the exploration and extraction processes of oil and gas, the natural radionuclides ${ }^{238} \mathrm{U}$, ${ }^{235} \mathrm{U}$, and ${ }^{232} \mathrm{Th}$, as well as the radium-radionuclides ${ }^{223} \mathrm{Ra}$, ${ }^{224} \mathrm{Ra}$, ${ }^{226} \mathrm{Ra}$ and ${ }^{228} \mathrm{Ra}$, and ${ }^{210} \mathrm{~Pb}$, etc., are brought to slurry surfaces and may contain levels of radioactivity above the surface background [4, 6]. Several studies have been conducted on the concentrations of naturally radionuclides in the environment in different regions throughout the world [7-13].

Radionuclides present in the environment may enter the human body through air, food, and water, thereby adversely affecting human health at higher radiation dose levels. Humans and other living organisms are continuously exposed to ionizing radiation from natural and anthropogenic sources that are present everywhere in the environment [8, 14-17].

The levels of background radiation vary significantly from area to area, and hence radiation doses received by the general public [18]. In Saudi Arabia there is a lack of scientific information concerning naturally occurring radioactive material wastes in the environment around the refinery area and petroleum industries. Therefore, knowledge about the distribution pattern of both anthropogenic and natural radionuclides plays an important role in minimizing the expected health risks to the general public. The present work deals with the measurement of specific activities of ${ }^{238} \mathrm{U},{ }^{226} \mathrm{Ra},{ }^{232} \mathrm{Th},{ }^{40} \mathrm{~K}$, and ${ }^{137} \mathrm{Cs}$, calculation of the radium equivalent activity, external and internal hazard indices, absorbed dose, and annual effective dose equivalent for Ras Tanura soil.

\section{Materials and Methods}

\section{Study Area}

The city of Ras Tanura is located on the Arabian Gulf in Eastern Province of Saudi Arabia and its geographical coordinates are $26^{\circ} 38^{\prime} 38^{\prime \prime} \mathrm{N}$ and $50^{\circ} 9^{\prime} 33^{\prime \prime} \mathrm{E}$. Seawater surrounds the city on three sides. The tide rise ranges from 1.5 to $2 \mathrm{~m}$ during the year. Its area is about $290 \mathrm{~km}^{2}$ and a population is 74,000 inhabitants. Wind is strong and blowing dust during the year - especially in summer. Ras Tanura is one of the most important cities in Saudi Arabia because of the presence of one of the largest and oldest oil refineries in the Middle East, which began operating in 1945 . Also, the study area contains a gas plant and two ports for shipping oil. West and south of the city, the coast is mainly composed of sand, mud, sediment, and sludge, while the east coast is composed of sand and marine sediments. In general, the soil in Ras Tanura is sandy and composed of calcareous soil that varies in depth, thickness, and composition. A number of spring waters are located to the west.

\section{Sampling and Sample Preparation for Gamma Spectroscopy}

Thirty four soil samples were collected from different locations in Ras Tanura city nearby oil refinery and around residential area (Table 1, Fig. 1). All samples were bulked as a single sample and dried in an oven at $70^{\circ} \mathrm{C}$ for 24 hours. After drying the samples and removing stones, leaves and foreign particles, soil samples were crushed and prepared for radiation counting by sieving through $0.2 \mathrm{~mm}$ mesh. Each sample was packed into $62.172 \mathrm{~cm}^{3}$ standard size can and tightly sealed and stored for one month to acquire secular equilibrium between ${ }^{226} \mathrm{Ra}$ and its progenies. Reference material was packed into the same standard size beaker for efficiency calibration [19].

\section{Experimental Setup}

A hyper-pure germanium detector (HPGe), coaxial type, p-type with relative efficiency of $20 \%$ was used. The resolution (FWHM) at $122 \mathrm{keV},{ }^{57} \mathrm{Co}$ is $0.934 \mathrm{keV}$, and at $1332 \mathrm{keV},{ }^{60} \mathrm{Co}$ is $1.79 \mathrm{keV}$. The detector is shielded with a low-level background lead shield. The HPGe was calibrated for efficiency using the reference material RGU-1 from IAEA. The certified activity of uranium is $400 \mathrm{ppm}$, which is equivalent to $4,960 \mathrm{~Bq} / \mathrm{kg}$. The energy transitions of the ${ }^{226} \mathrm{Ra}$ daughters $\left({ }^{214} \mathrm{~Pb}\right.$ and $\left.{ }^{214} \mathrm{Bi}\right)$ were used to develop the efficiency calibration curve [19-20]. A $4^{\text {th }}$-degree polynomial fitting was performed to reach the best $\mathrm{R}^{2}$ value $(=0.983)$.

\section{Gamma-Spectrometric Analysis}

The gamma transmissions used for activity calculations are ${ }^{214} \mathrm{~Pb}$ with energies $295.2 \mathrm{keV}$ and $351.93 \mathrm{keV}$, and ${ }^{214} \mathrm{Bi}$ with energies $609.31 \mathrm{keV}$, $1120.29 \mathrm{keV}$, and $1764.49 \mathrm{keV}$ for ${ }^{226} \mathrm{Ra}\left({ }^{238} \mathrm{U}\right)$ series. For ${ }^{232} \mathrm{Th}$, the specific activity concentration was determined using the gamma lines $338.40 \mathrm{keV}$ and $911.07 \mathrm{keV}$ for ${ }^{228} \mathrm{Ac}$ and $583.14 \mathrm{keV}$ for ${ }^{208} \mathrm{Tl}$. The average values were calculated. In the case of ${ }^{40} \mathrm{~K}$ and ${ }^{137} \mathrm{Cs}$, the specific activity concentrations were estimated directly by their gamma lines of $1460.75 \mathrm{keV}$ and $661.7 \mathrm{keV}$, respectively [19]. The software used for analysis and reducing the gammaray spectra was Quantum Gold version 4.04.00. The minimum detectable activity (MDA) for each isotope $\left({ }^{226} \mathrm{Ra},{ }^{232} \mathrm{Th},{ }^{40} \mathrm{~K}\right.$, and $\left.{ }^{137} \mathrm{Cs}\right)$ in the background was calculated separately based on the 
Table 1. Activities concentrations of ${ }^{238} \mathrm{U},{ }^{226} \mathrm{Ra},{ }^{232} \mathrm{Th},{ }^{40} \mathrm{~K}$, and ${ }^{137} \mathrm{Cs}(\mathrm{Bq} / \mathrm{kg})$ in soil samples collected from different sites in Ras Tanura.

\begin{tabular}{|c|c|c|c|c|c|c|c|}
\hline Sample ID & Latitude & Longitude & ${ }^{238} \mathrm{U}$ & ${ }^{226} \mathrm{Ra}$ & ${ }^{232} \mathrm{Th}$ & ${ }^{40} \mathrm{~K}$ & ${ }^{137} \mathrm{Cs}$ \\
\hline S1 & $26^{\circ} 42^{\prime} 29.1^{\prime \prime} \mathrm{N}$ & $50^{\circ} 5^{\prime} 46.7^{\prime \prime} \mathrm{E}$ & $40.6 \pm 9$ & $8.68 \pm 0.6$ & $3.21 \pm 0.6$ & $108 \pm 5.4$ & $<\mathrm{MDA}^{*}$ \\
\hline S2 & $26^{\circ} 42^{\prime} 45.9^{\prime \prime} \mathrm{N}$ & $50^{\circ} 5^{\prime} 20.1^{\prime \prime} \mathrm{E}$ & $40.2 \pm 11$ & $9.49 \pm 0.4$ & $2.76 \pm 0.2$ & $116 \pm 4.6$ & $<\mathrm{MDA}$ \\
\hline S3 & $46^{\circ} 42^{\prime} 59.1^{\prime \prime} \mathrm{N}$ & $50^{\circ} 4^{\prime} 57.8^{\prime \prime} \mathrm{E}$ & $55.3 \pm 7.7$ & $9.46 \pm 0.5$ & $3.59 \pm 0.6$ & $129 \pm 6.4$ & $<$ MDA \\
\hline S4 & $26^{\circ} 43^{\prime} 15.4^{\prime \prime} \mathrm{N}$ & $50^{\circ} 4^{\prime} 35.2^{\prime \prime} \mathrm{E}$ & $41.4 \pm 7.9$ & $13.1 \pm 0.7$ & $3.03 \pm 0.4$ & $132 \pm 7.5$ & $<$ MDA \\
\hline S5 & $26^{\circ} 42^{\prime} 44.3^{\prime \prime} \mathrm{N}$ & $50^{\circ} 4^{\prime} 51.7^{\prime \prime} \mathrm{E}$ & $31.1 \pm 8.4$ & $9.93 \pm 0.9$ & $2.84 \pm 0.4$ & $115 \pm 6.4$ & $<\mathrm{MDA}$ \\
\hline S6 & $26^{\circ} 43^{\prime} 15.7^{\prime \prime} \mathrm{N}$ & $50^{\circ} 4^{\prime} 18.0^{\prime \prime} \mathrm{E}$ & $24.2 \pm 7.2$ & $69.3 \pm 3.3$ & $9.78 \pm 1.1$ & $389 \pm 13$ & $0.50 \pm 0.1$ \\
\hline S7 & $26^{\circ} 43^{\prime} 26.4^{\prime \prime} \mathrm{N}$ & $50^{\circ} 3^{\prime} 57.1^{\prime \prime} \mathrm{E}$ & $25.2 \pm 7.6$ & $20.9 \pm 1.9$ & $6.34 \pm 1.3$ & $311 \pm 9.9$ & $<$ MDA \\
\hline S8 & $26^{\circ} 44^{\prime} 25.1^{\prime \prime} \mathrm{N}$ & $50^{\circ} 3^{\prime} 45.2^{\prime \prime} \mathrm{E}$ & $39.3 \pm 9.9$ & $10.6 \pm 0.5$ & $4.93 \pm 0.6$ & $195 \pm 8.9$ & $1.71 \pm 0.3$ \\
\hline S9 & $26^{\circ} 45^{\prime} 35.5^{\prime \prime} \mathrm{N}$ & $50^{\circ} 2^{\prime} 15.6^{\prime \prime} \mathrm{E}$ & $51.5 \pm 9.9$ & $12.5 \pm 0.9$ & $4.80 \pm 0.9$ & $147 \pm 7.5$ & $1.30 \pm 0.3$ \\
\hline $\mathrm{S} 10$ & $26^{\circ} 45^{\prime} 58.6^{\prime \prime} \mathrm{N}$ & $50^{\circ} 1^{\prime} 59.3^{\prime \prime} \mathrm{E}$ & $45.4 \pm 13$ & $14.2 \pm 1.5$ & $4.69 \pm 1.0$ & $205 \pm 9.9$ & $1.48 \pm 0.3$ \\
\hline S11 & $26^{\circ} 42^{\prime} 18.7^{\prime \prime} \mathrm{N}$ & $50^{\circ} 4^{\prime} 39.5^{\prime \prime} \mathrm{E}$ & $42.5 \pm 7.4$ & $19.5 \pm 2.0$ & $8.76 \pm 1.2$ & $294 \pm 12$ & $0.20 \pm 0.04$ \\
\hline $\mathrm{S} 12$ & $26^{\circ} 42^{\prime} 15.8^{\prime \prime} \mathrm{N}$ & $50^{\circ} 4^{\prime} 35.7^{\prime \prime} \mathrm{E}$ & $29.6 \pm 8.8$ & $19.9 \pm 1.6$ & $9.05 \pm 0.4$ & $344 \pm 9.9$ & $0.18 \pm 0.04$ \\
\hline $\mathrm{S} 13$ & $26^{\circ} 42^{\prime} 5.20^{\prime \prime} \mathrm{N}$ & $50^{\circ} 4^{\prime} 20.6^{\prime \prime} \mathrm{E}$ & $26.8 \pm 6.4$ & $22.7 \pm 1.8$ & $8.96 \pm 0.5$ & $357 \pm 9.6$ & $1.23 \pm 0.3$ \\
\hline S14 & $26^{\circ} 41^{\prime} 52.2^{\prime \prime} \mathrm{N}$ & $50^{\circ} 4^{\prime} 9.30^{\prime \prime} \mathrm{E}$ & $39.7 \pm 8.8$ & $31.1 \pm 1.5$ & $10.08 \pm 1.7$ & $362 \pm 11$ & $<\mathrm{MDA}$ \\
\hline S15 & $26^{\circ} 41^{\prime} 48.4^{\prime \prime} \mathrm{N}$ & $50^{\circ} 3^{\prime} 53.7^{\prime \prime} \mathrm{E}$ & $62.8 \pm 7.7$ & $67.8 \pm 3.8$ & $12.8 \pm 1.8$ & $311 \pm 17$ & $<\mathrm{MDA}$ \\
\hline S16 & $26^{\circ} 41^{\prime} 44.2^{\prime \prime} \mathrm{N}$ & $50^{\circ} 3^{\prime} 27.8^{\prime \prime} \mathrm{E}$ & $45.1 \pm 8.7$ & $30.4 \pm 2.8$ & $8.90 \pm 0.8$ & $446 \pm 12$ & $1.3 \pm 0.3$ \\
\hline $\mathrm{S} 17$ & $26^{\circ} 41^{\prime} 44.6^{\prime \prime} \mathrm{N}$ & $50^{\circ} 3^{\prime} 8.50^{\prime \prime} \mathrm{E}$ & $58.5 \pm 9.8$ & $37.5 \pm 2.9$ & $12.1 \pm 1.3$ & $453 \pm 13$ & $<\mathrm{MDA}$ \\
\hline $\mathrm{S} 18$ & $26^{\circ} 41^{\prime} 42.1^{\prime \prime} \mathrm{N}$ & $50^{\circ} 2^{\prime} 21.8^{\prime \prime} \mathrm{E}$ & $41.5 \pm 6.0$ & $156 \pm 3.9$ & $11.9 \pm 1.7$ & $407 \pm 13$ & $3.83 \pm 0.6$ \\
\hline S19 & $26^{\circ} 41^{\prime} 50.1^{\prime \prime} \mathrm{N}$ & $50^{\circ} 2^{\prime} 21.8^{\prime \prime} \mathrm{E}$ & $45.0 \pm 7.2$ & $16.3 \pm 1.1$ & $9.58 \pm 0.6$ & $344 \pm 12$ & $1.73 \pm 0.3$ \\
\hline S20 & $26^{\circ} 41^{\prime} 49.7^{\prime \prime} \mathrm{N}$ & $50^{\circ} 1^{\prime} 58.7^{\prime \prime} \mathrm{E}$ & $46.2 \pm 6.6$ & $17.5 \pm 1.3$ & $8.67 \pm 1.3$ & $406 \pm 11$ & $<\mathrm{MDA}$ \\
\hline $\mathrm{S} 21$ & $26^{\circ} 42^{\prime} 14.6^{\prime \prime} \mathrm{N}$ & $50^{\circ} 1^{\prime} 51.1^{\prime \prime} \mathrm{E}$ & $27.2 \pm 5.7$ & $17.6 \pm 2.3$ & $12.2 \pm 0.6$ & $346 \pm 10$ & $1.61 \pm 0.3$ \\
\hline $\mathrm{S} 22$ & $26^{\circ} 42^{\prime} 37.3^{\prime \prime} \mathrm{N}$ & $50^{\circ} 1^{\prime} 38.9^{\prime \prime} \mathrm{E}$ & $29.9 \pm 6.4$ & $16.2 \pm 1.2$ & $8.89 \pm 1.5$ & $335 \pm 14$ & $<\mathrm{MDA}$ \\
\hline S23 & $26^{\circ} 43^{\prime} 4.70^{\prime \prime} \mathrm{N}$ & $50^{\circ} 1^{\prime} 27.1^{\prime \prime} \mathrm{E}$ & $37.4 \pm 7.0$ & $19.3 \pm 1.7$ & $11.0 \pm 1.8$ & $400 \pm 11$ & $<\mathrm{MDA}$ \\
\hline S24 & $26^{\circ} 43^{\prime} 32.9^{\prime \prime} \mathrm{N}$ & $50^{\circ} 1^{\prime} 9.70^{\prime \prime} \mathrm{E}$ & $51.5 \pm 7.4$ & $17.3 \pm 1.4$ & $9.44 \pm 1.6$ & $249 \pm 10$ & $1.36 \pm 0.3$ \\
\hline S25 & $26^{\circ} 43^{\prime} 41.7^{\prime \prime} \mathrm{N}$ & $50^{\circ} 1^{\prime} 22.4^{\prime \prime} \mathrm{E}$ & $19.0 \pm 4.4$ & $21.5 \pm 1.4$ & $11.0 \pm 1.6$ & $425 \pm 13$ & $<\mathrm{MDA}$ \\
\hline S26 & $26^{\circ} 45^{\prime} 7.70^{\prime \prime} \mathrm{N}$ & $50^{\circ} 1^{\prime} 58.6^{\prime \prime} \mathrm{E}$ & $25.1 \pm 5.1$ & $9.96 \pm 0.8$ & $5.85 \pm 1.0$ & $172 \pm 6.4$ & $0.24 \pm 0.05$ \\
\hline S27 & $26^{\circ} 45^{\prime} 31.3^{\prime \prime} \mathrm{N}$ & $50^{\circ} 1^{\prime} 28.9^{\prime \prime} \mathrm{E}$ & $51.9 \pm 10$ & $16.5 \pm 1.1$ & $5.81 \pm 0.6$ & $229 \pm 7.4$ & $0.79 \pm 0.2$ \\
\hline $\mathrm{S} 28$ & $26^{\circ} 43^{\prime} 57.6^{\prime \prime} \mathrm{N}$ & $50^{\circ} 3^{\prime} 16.4^{\prime \prime} \mathrm{E}$ & $43.8 \pm 8.6$ & $14.7 \pm 0.8$ & $8.40 \pm 1.2$ & $213 \pm 8.1$ & $1.85 \pm 0.4$ \\
\hline S29 & $26^{\circ} 43^{\prime} 34.4^{\prime \prime} \mathrm{N}$ & $50^{\circ} 3^{\prime} 11.7^{\prime \prime} \mathrm{E}$ & $45.3 \pm 7.6$ & $20.5 \pm 1.1$ & $9.24 \pm 1.2$ & $257 \pm 10$ & $2.50 \pm 0.5$ \\
\hline $\mathrm{S} 30$ & $26^{\circ} 43^{\prime} 22.1^{\prime \prime} \mathrm{N}$ & $50^{\circ} 2^{\prime} 52.8^{\prime \prime} \mathrm{E}$ & $46.7 \pm 7.1$ & $14.7 \pm 0.7$ & $9.04 \pm 0.9$ & $340 \pm 9.8$ & $3.55 \pm 0.5$ \\
\hline $\mathrm{S} 31$ & $26^{\circ} 43^{\prime} 4.90^{\prime \prime} \mathrm{N}$ & $50^{\circ} 3^{\prime} 0.40^{\prime \prime} \mathrm{E}$ & $39.6 \pm 5.8$ & $23.5 \pm 1.5$ & $9.70 \pm 0.7$ & $301 \pm 10$ & $<\mathrm{MDA}$ \\
\hline $\mathrm{S} 32$ & $26^{\circ} 43^{\prime} 13.3^{\prime \prime} \mathrm{N}$ & $50^{\circ} 3^{\prime} 23.0^{\prime \prime} \mathrm{E}$ & $24.1 \pm 4.8$ & $20.8 \pm 1.4$ & $10.1 \pm 1.4$ & $385 \pm 10$ & $<\mathrm{MDA}$ \\
\hline $\mathrm{S} 33$ & $26^{\circ} 43^{\prime} 4.00^{\prime \prime} \mathrm{N}$ & $50^{\circ} 3^{\prime} 28.2^{\prime \prime} \mathrm{E}$ & $25.4 \pm 5.0$ & $14.1 \pm 0.9$ & $11.8 \pm 0.7$ & $431 \pm 11$ & $0.94 \pm 0.1$ \\
\hline S34 & $26^{\circ} 42^{\prime} 52.2^{\prime \prime} \mathrm{N}$ & $50^{\circ} 3^{\prime} 6.60^{\prime \prime} \mathrm{E}$ & $32.3 \pm 6.4$ & $20.7 \pm 1.0$ & $10.8 \pm 1.2$ & $345 \pm 9.4$ & $<\mathrm{MDA}$ \\
\hline
\end{tabular}

*MDA is the minimum detectable activity.

sample's weight $(90 \mathrm{gm})$ using the detection limit according to the formula [21]:

$$
\operatorname{MDA}(\mathrm{Bq})=\left(2.7+4.65(\mathrm{BG})^{1 / 2}\right) /\left(\varepsilon \mathrm{I}_{\gamma} \mathrm{t}\right)
$$

...where BG is the background count below the peak of interest, $\varepsilon$ is absolute efficiency, $\mathrm{I}_{\gamma}$ is gamma line intensity, and $\mathrm{t}$ is the counting time in seconds. The MDAs for ${ }^{226} \mathrm{Ra},{ }^{232} \mathrm{Th},{ }^{40} \mathrm{~K}$, and ${ }^{137} \mathrm{Cs}$ were $0.18,0.11$, 0.94 , and $0.003 \mathrm{~Bq}$, respectively. 


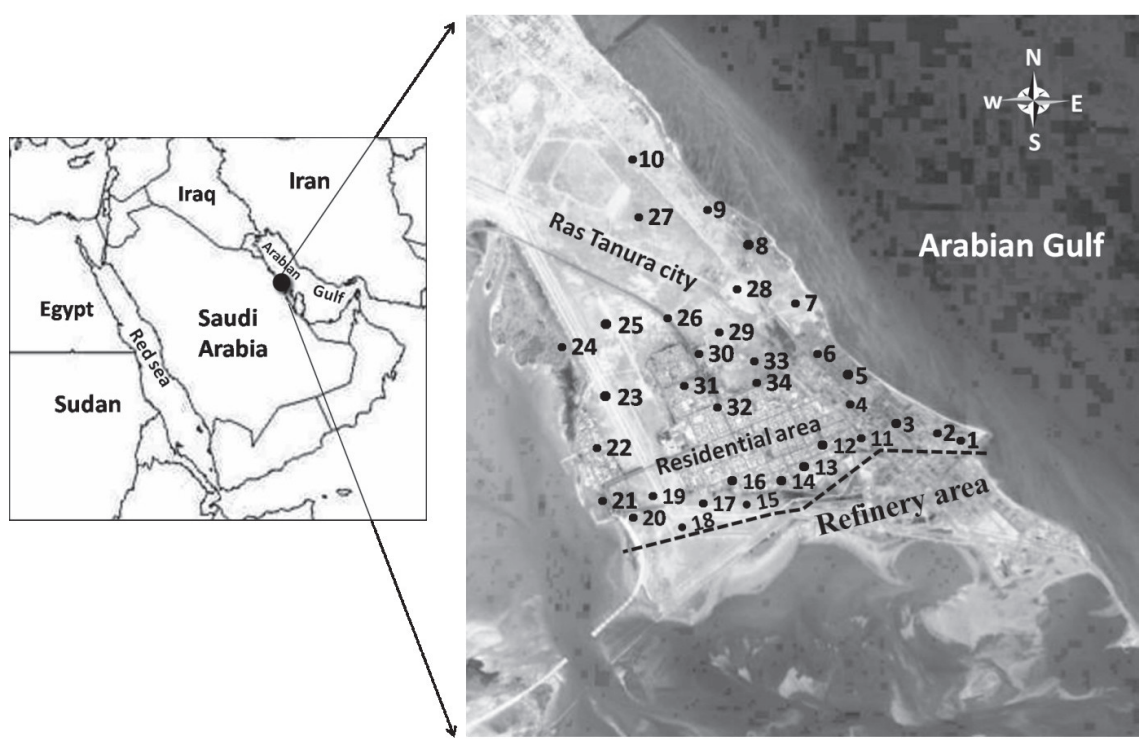

Fig. 1. Location map of soil samples, Ras Tanura, Arabian Gulf, Saudi Arabia.

\section{Results and Discussion}

\section{Activity Concentrations}

The activity concentrations of naturally occurring radionuclides $\left({ }^{238} \mathrm{U},{ }^{226} \mathrm{Ra}{ }^{232} \mathrm{Th},{ }^{40} \mathrm{~K}\right.$, and $\left.{ }^{137} \mathrm{Cs}\right)$ were determined in soil samples from Ras Tanura city, Saudi Arabia. The statistics of the activity concentrations expressed in $\mathrm{Bq} / \mathrm{kg}$ are presented in Tables 1 and 2. The activity concentrations of ${ }^{238} \mathrm{U}$ ranged from $19.0 \pm 4.4$ to $62.8 \pm 7.7 \mathrm{~Bq} / \mathrm{kg}$, with a mean value of $39.0 \pm 4.8 \mathrm{~Bq} / \mathrm{kg}$. The activity concentrations of ${ }^{226} \mathrm{Ra}$ ranged from $8.68 \pm 0.6$ to $156 \pm 3.6 \mathrm{~Bq} / \mathrm{kg}$, with a mean value of $23.2 \pm 1.4 \mathrm{~Bq} / \mathrm{kg}$. The highest activity concentration of Radium was found to be $156 \pm 3.6 \mathrm{~Bq} / \mathrm{kg}$ for soil sample S18, which was higher than the allowed limit of $30 \mathrm{~Bq} / \mathrm{kg}$ [22]. The site of this sample is located in an area composed of sandy soil, marine sediments, and mud. The high value of radium in sample 18 may be attributed to the near of the sample collection site from the sludge area, where the NORM waste is concentrated and accumulates in the environment in the form of sludge and scale. Sludge area may contain a level of radioactivity above the surface background, where radium is the most important naturally occurring radionuclide content in sludge [23-24].
The activity concentrations of ${ }^{232} \mathrm{Th}$ ranged from $2.76 \pm 0.2$ to $12.8 \pm 1.8 \mathrm{~Bq} / \mathrm{kg}$ with a mean value of $7.73 \mathrm{~Bq} / \mathrm{kg}$. The concentrations of ${ }^{40} \mathrm{~K}$ and ${ }^{137} \mathrm{Cs}$ ranged from $108 \pm 5.4$ to $446 \pm 12 \mathrm{~Bq} / \mathrm{kg}$ and from below the MDA to $3.83 \pm 0.6 \mathrm{~Bq} / \mathrm{kg}$, respectively. The obtained results show that the mean values of ${ }^{40} \mathrm{~K}$ concentrations in soil samples were lower than the range of the world average $370 \mathrm{~Bq} / \mathrm{kg}$ [22]. The activity level of ${ }^{137} \mathrm{Cs}$ was found to be lower than the minimum detection limit in $44 \%$ of soil samples. The variations in activity concentrations of ${ }^{226} \mathrm{Ra},{ }^{232} \mathrm{Th}$, and ${ }^{40} \mathrm{~K}$ in soil samples are based on the nature of its geological formations in the study area. Otherwise, naturally occurring radioactive materials encountered in oil and gas exploration, development, and production operations originate in subsurface formations that may contain radioactive materials such as uranium, thorium, and their daughter products [25]. This can be brought to the surface and contribute in the surface background. In addition, some weather phenomena such as rainfall and direction of wind may contribute to the distribution of radionuclides in the study area during the year.

The low values of the standard deviations obtained for the three radionuclides show the relative uniformity in the distribution of the radionuclides within the study

Table 2. Descriptive statistical parameters of ${ }^{238} \mathrm{U},{ }^{226} \mathrm{Ra},{ }^{232} \mathrm{Th},{ }^{40} \mathrm{~K}$, and ${ }^{137} \mathrm{Cs}(\mathrm{Bq} / \mathrm{kg})$ in soil samples collected from different sites in Ras Tanura.

\begin{tabular}{|c|c|c|c|c|c|}
\hline Radionuclides & ${ }^{238} \mathrm{U}$ & ${ }^{226} \mathrm{Ra}$ & ${ }^{232} \mathrm{Th}$ & ${ }^{40} \mathrm{~K}$ & ${ }^{137} \mathrm{Cs}$ \\
\hline Min. & $19.0 \pm 4.4$ & $8.68 \pm 0.6$ & $2.76 \pm 0.2$ & $108 \pm 5.4$ & $<\mathrm{MDA}$ \\
\hline Max. & $62.8 \pm 7.7$ & $156 \pm 3.9$ & $12.8 \pm 1.8$ & $446 \pm 12$ & $3.83 \pm 0.6$ \\
\hline Mean & $39.0 \pm 4.8$ & $23.2 \pm 1.4$ & $7.73 \pm 1.2$ & $278 \pm 9.8$ & $1.42 \pm 0.5$ \\
\hline Std. Deviation & 10.99 & 26.92 & 3.02 & 108 & -- \\
\hline Std. Error & 1.89 & 4.62 & 0.52 & 18.44 & -- \\
\hline
\end{tabular}


area. The distribution also reflects uniformity in the geology of the study area. The relative contribution to dose due to ${ }^{40} \mathrm{~K}$ was $80 \%$, and ${ }^{238} \mathrm{U}$ was $11 \%$, followed by the contribution due to ${ }^{226} \mathrm{Ra}$ and ${ }^{232} \mathrm{Th}$ as $7 \%$ and $2 \%$, respectively, while ${ }^{137} \mathrm{Cs}$ do not contribute to the dose rate (Fig. 2). In order to test the correlations between ${ }^{238} \mathrm{U}$ versus ${ }^{226} \mathrm{Ra}$ and ${ }^{232} \mathrm{Th}$ and ${ }^{238} \mathrm{U}$ versus ${ }^{137} \mathrm{Cs}$, the correlations between uranium and these radionuclides were plotted as shown in Figs 3-4. The results show weak relationships between ${ }^{238} \mathrm{U}$ versus ${ }^{226} \mathrm{Ra}$ and ${ }^{232} \mathrm{Th}$ with correlation coefficient values $(\mathrm{R})$ of 0.008 and 0.008 , respectively. Similarly, the relationship between ${ }^{238} \mathrm{U}$ and ${ }^{137} \mathrm{Cs}$ was poor correlation with correlation coefficient value $(\mathrm{R})$ of 0.034 . The poor correlation between uranium and other radionuclides may be due to the possible input of radium, thorium, and cesium in soil as a result of oil exploration activites. According to the recommended reference level of 30,35 , and $400 \mathrm{~Bq} / \mathrm{kg}$ for ${ }^{226} \mathrm{Ra},{ }^{232} \mathrm{Th}$, and ${ }^{40} \mathrm{~K}$, respectively, for the world average concentrations published by the United Nations Scientific Committee on the Effects of Atomic Radiation [22], it is noted that the obtained results in most samples are lower than the recommended reference levels.

The activity concentration measured in this study was compared with those from local and other countries (Table 3) [7, 26, 30-45]. The values of ${ }^{226} \mathrm{Ra}$ activity concentration in our study are lower than the values in similar studies in Yemen, Hungary, Yunnan, China, Turkey, Thailand, Algeria, Egypt, Pakistan, Iraq, and Jordan, while it is little higher than that of Sudan, Nigeria, and Malaysia, and within the range of India. The mean value of ${ }^{232} \mathrm{Th}$ activity concentration in the study area was less than those of all compared countries. Similarly, the mean value of ${ }^{40} \mathrm{~K}$ activity concentration in the study area was less than the values of all countries except Nigeria, Jordan, Sudan, and Malaysia. However, the mean values of ${ }^{226} \mathrm{Ra},{ }^{232} \mathrm{Th}$, and ${ }^{40} \mathrm{~K}$ in the present study are within the range of the local studies from Qassim (north), Albaha (south), and Riyadh (middle). Variations of radioactivity levels in soil locally

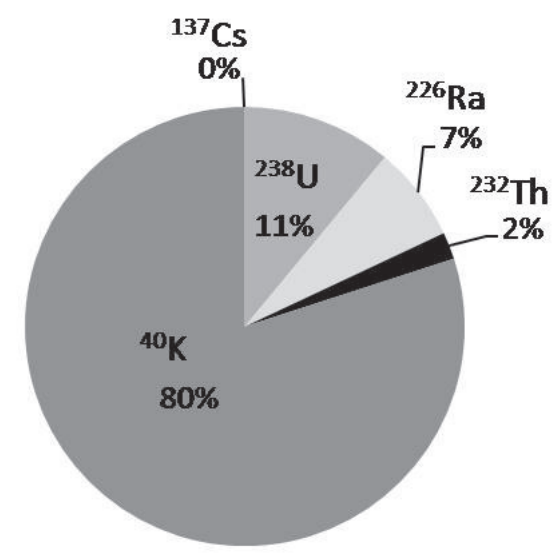

Fig. 2. Percentage contribution of ${ }^{238} \mathrm{U},{ }^{226} \mathrm{Ra},{ }^{232} \mathrm{Th}$, and ${ }^{40} \mathrm{~K}$ in activity concentration for Ras Tanura soil. and in other countries worldwide may depend upon geological and geographical conditions of the area and the presence of NORM, or the applications of phosphate fertilizers in agricultural soil $[19,26]$. Some of these countries have a geological structure that differs from the geology of Ras Tanura. Soils from Sudan, Yemen, and Nigeria contain volcanic sediments, while soils from Jordan and Egypt are composed mainly of coarse sand and sandy loam mixed with limestone, marble, and gravel. Similarly, the geology of the study area in Hungary and Yunnan is sandstone, clay rocks, and a few tens of kilometers are granitic stock, while the geological nature of Iraq is similar to Ras Tanura geology along the Arabian Gulf.

\section{Radiological Parameters}

Radium Equivalent Activities $\left(R a_{e q}\right)$

The Gamma- ray radiation hazards in soil due to the specified radionuclides ${ }^{226} \mathrm{Ra},{ }^{232} \mathrm{Th}$, and ${ }^{40} \mathrm{~K}$ can be assessed using different indices. Radium equivalent activity, $\mathrm{Ra}_{\mathrm{eq}}$, is the most widely used as a radiation

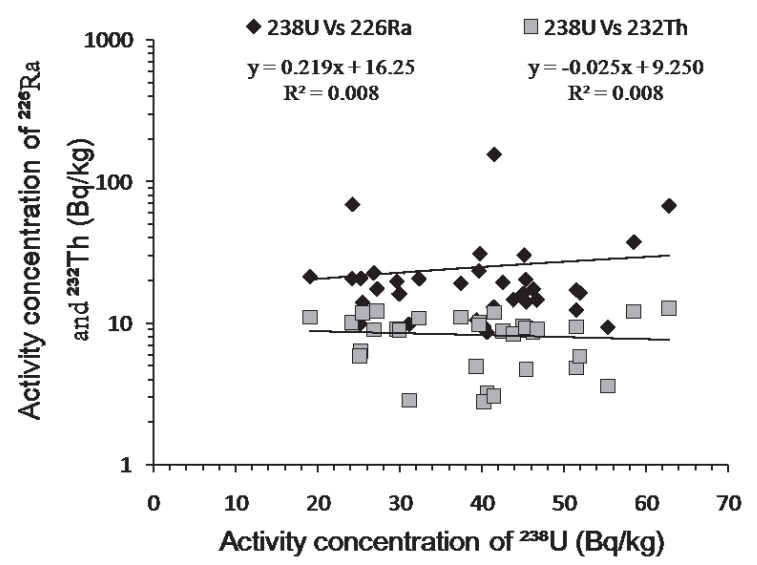

Fig. 3. Correlations between ${ }^{238} \mathrm{U}$ with ${ }^{226} \mathrm{Ra}$ and ${ }^{232} \mathrm{Th}$ for Ras Tanura soil.

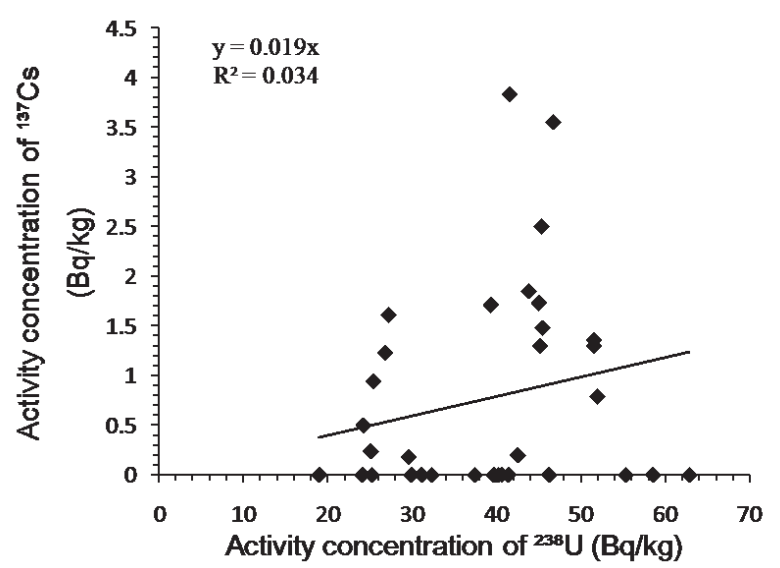

Fig. 4. Correlation between ${ }^{238} \mathrm{U}$ with ${ }^{137} \mathrm{Cs}$ for Ras Tanura soil. 
Table 3. Comparison of radioactivity levels in local and global soil samples.

\begin{tabular}{|c|c|c|c|c|}
\hline Country & $\begin{array}{c}{ }^{226} \mathrm{Ra} \\
(\mathrm{Bq} / \mathrm{kg})\end{array}$ & $\begin{array}{c}{ }^{232} \mathrm{Th} \\
(\mathrm{Bq} / \mathrm{kg})\end{array}$ & $\begin{array}{c}{ }^{40} \mathrm{~K} \\
(\mathrm{~Bq} / \mathrm{kg})\end{array}$ & Reference \\
\hline China & 134 & 187 & 680 & [21] \\
\hline Sudan & 7.54 & 20.74 & 111.87 & [22] \\
\hline Jordan & 57.7 & 18.1 & 138.1 & [23] \\
\hline Hungary & 29.7 & 32.1 & 418 & [24] \\
\hline Egypt & 46.15 & 30.57 & 553.14 & [25] \\
\hline Yunnan & 53.4 & 120.9 & 632.2 & [26] \\
\hline Pakistan & 45 & 59 & 648 & [27] \\
\hline Thailand & $54.5-65.4$ & $60.7-69.1$ & $393-478$ & [28] \\
\hline Nigeria & 18 & 22 & 210 & [29] \\
\hline Yemen & 44.4 & 58.2 & 822.7 & [30] \\
\hline Algeria & 53.2 & 50.0 & 311.4 & [31] \\
\hline Turkey & 48.4 & 20.5 & 744.8 & [32] \\
\hline Malaysia & 6.56 & 10.62 & 41.02 & [33] \\
\hline India & $18-46$ & $53-92$ & $248-756$ & [34] \\
\hline Iraq & 58.44 & 19.38 & 321.76 & [35] \\
\hline Qassim, Saudi Arabia (North) & 14.1 & 15.5 & 143.1 & {$[17]$} \\
\hline Albaha, Saudi Arabia (South) & 37 & 23 & 343 & {$[36]$} \\
\hline Riyadh, Saudi Arabia (Middle) & 14.5 & 11.2 & 225 & {$[37]$} \\
\hline Ras Tanura, Saudi Arabia (East) & 23.19 & 7.73 & 278 & Present work \\
\hline
\end{tabular}

hazard index associated with the three radionuclides of ${ }^{226} \mathrm{Ra},{ }^{232} \mathrm{Th}$, and ${ }^{40} \mathrm{~K}$. Ra eq is a weighted sum of activities of these radionuclides based on the estimation that 370 $\mathrm{Bq} / \mathrm{kg}$ of ${ }^{226} \mathrm{Ra}, 259 \mathrm{~Bq} / \mathrm{kg}$ of ${ }^{232} \mathrm{Th}$, and $4810 \mathrm{~Bq} / \mathrm{kg}$ of ${ }^{40} \mathrm{~K}$ produce the same $\gamma$-ray dose rates. $\mathrm{Ra}_{\text {eq }}$ is given by the following equation $[19,22]$ :

$$
\mathrm{Ra}_{\mathrm{eq}}(\mathrm{Bq} / \mathrm{kg})=\mathrm{A}_{\mathrm{Ra}}+1.43 \mathrm{~A}_{\mathrm{Th}}+0.077 \mathrm{~A}_{\mathrm{K}}
$$

...where $\mathrm{A}_{\mathrm{Ra}}, \mathrm{A}_{\mathrm{Th}}$, and $\mathrm{A}_{\mathrm{K}}$ are the activity concentrations $(\mathrm{Bq} / \mathrm{kg})$ of ${ }^{226} \mathrm{Ra},{ }^{232} \mathrm{Th}$, and ${ }^{40} \mathrm{~K}$, respectively. When the value of $\mathrm{Ra}_{\mathrm{eq}}$ is $370 \mathrm{~Bq} / \mathrm{kg}$, this corresponds to $1 \mathrm{mSv} / \mathrm{y}$. The radium equivalent concept allows a single index or number, which is a widely used hazard index to describe the gamma output from different mixtures of radium, thorium, and potassium in the soil samples from different locations. The calculated values vary from 21.6 (sample No. 1) to 204 (sample No. 18) Bq/ $\mathrm{kg}$ with an average of $62.1 \mathrm{~Bq} / \mathrm{kg}$ (Table 4). These values are lower than the permissible maximum value of 370 $\mathrm{Bq} / \mathrm{kg}$ [22].

\section{Absorbed Dose Rate (D)}

The absorbed gamma dose rate $\mathrm{D}(\mathrm{nGy} / \mathrm{h})$ in air at $1 \mathrm{~m}$ above the ground surface for the uniform distribution of radionuclides were calculated based on guidelines provided by [22]:

$$
\mathrm{D}(\mathrm{nGy} / \mathrm{h})=0.462 \mathrm{~A}_{\mathrm{Ra}}+0.604 \mathrm{~A}_{\mathrm{Th}}+0.0417 \mathrm{~A}_{\mathrm{K}}
$$

...where $A_{R a}, A_{T h}$, and $A_{K}$ are the activity concentrations $(\mathrm{Bq} / \mathrm{kg})$ of ${ }^{226} \mathrm{Ra},{ }^{232} \mathrm{Th}$, and ${ }^{40} \mathrm{~K}$, respectively, in the samples. The absorbed dose rate expresses the received dose in the open air from the radiation emitted from radionuclide concentrations in environmental materials. Also, it is the first major step for evaluating health risk and is expressed in Gray (Gy). The calculated total absorbed dose rates of samples are tabulated in Table 3. It is observed that the total absorbed dose rate resulting from ${ }^{226} \mathrm{Ra},{ }^{232} \mathrm{Th}$, and ${ }^{40} \mathrm{~K}$ ranges between 10.5 (sample 1) to 96.4 (sample 18), and the average value was 29.3, which was lower than the limits as recommended by the International Commission on Radiological Protection, $55 \mathrm{nGy} / \mathrm{h}$ [27]. The highest value in site No. 18 is slightly higher than the world average. This value is due to the significant amount of radium, which reflects the highest value of absorbed gamma dose rate in soil sample 18. The location of this soil sample was observed close to the sludge area, and consists of sand mixed with a large amount of suspended materials which are thought to be re-sedimented. 
Table 4. Radium equivalent activity $\left(\mathrm{Ra}_{\mathrm{eq}}\right)$, air absorbed gamma radiation dose rate $(\mathrm{D})$, annual effective dose equivalent outdoor $\left(\mathrm{E}_{\text {out }}\right)$, annual effective dose equivalent indoor $\left(\mathrm{E}_{\text {in }}\right)$, internal radiation hazard index $\left(\mathrm{H}_{\text {in }}\right)$, external radiation hazard index $\left(\mathrm{H}_{e x}\right)$, and representative level index $\left(\mathrm{I}_{\gamma \mathrm{r}}\right)$ for soil samples.

\begin{tabular}{|c|c|c|c|c|c|c|c|}
\hline Sample ID & $\begin{array}{c}\mathrm{Ra}_{\mathrm{eq}} \\
(\mathrm{Bq} / \mathrm{kg})\end{array}$ & $\begin{array}{c}\mathrm{D} \\
(\mathrm{nGy} / \mathrm{h}) \\
\end{array}$ & $\begin{array}{c}E_{\text {out }} \\
(\mathrm{mSv} / \mathrm{y})\end{array}$ & $\begin{array}{c}E_{\text {in }} \\
(m S v / y)\end{array}$ & $\mathrm{H}_{\mathrm{ex}}$ & $\mathrm{H}_{\mathrm{in}}$ & $I_{\gamma r}$ \\
\hline $\mathrm{S} 1$ & 21.6 & 10.5 & 0.013 & 0.052 & 0.058 & 0.082 & 0.162 \\
\hline S2 & 22.4 & 10.9 & 0.013 & 0.053 & 0.060 & 0.086 & 0.168 \\
\hline S3 & 24.5 & 12.0 & 0.015 & 0.059 & 0.066 & 0.092 & 0.185 \\
\hline S4 & 27.6 & 13.4 & 0.016 & 0.066 & 0.075 & 0.110 & 0.206 \\
\hline S5 & 22.8 & 11.1 & 0.014 & 0.054 & 0.062 & 0.089 & 0.171 \\
\hline S6 & 113 & 54.3 & 0.067 & 0.266 & 0.306 & 0.493 & 0.819 \\
\hline S7 & 53.9 & 26.6 & 0.033 & 0.130 & 0.146 & 0.202 & 0.410 \\
\hline S8 & 32.7 & 16.1 & 0.020 & 0.079 & 0.088 & 0.117 & 0.250 \\
\hline S9 & 30.7 & 14.9 & 0.018 & 0.073 & 0.083 & 0.117 & 0.229 \\
\hline S10 & 36.7 & 18.0 & 0.022 & 0.088 & 0.099 & 0.137 & 0.278 \\
\hline S11 & 54.7 & 26.7 & 0.033 & 0.131 & 0.148 & 0.200 & 0.414 \\
\hline S12 & 59.3 & 29.2 & 0.036 & 0.143 & 0.160 & 0.214 & 0.453 \\
\hline S13 & 63.0 & 30.9 & 0.038 & 0.152 & 0.170 & 0.232 & 0.479 \\
\hline S14 & 73.4 & 35.7 & 0.044 & 0.175 & 0.198 & 0.282 & 0.549 \\
\hline S15 & 110 & 52.2 & 0.064 & 0.256 & 0.297 & 0.481 & 0.787 \\
\hline S16 & 77.5 & 38.2 & 0.047 & 0.187 & 0.209 & 0.291 & 0.589 \\
\hline S17 & 89.7 & 43.7 & 0.054 & 0.214 & 0.242 & 0.344 & 0.673 \\
\hline S18 & 204 & 96.4 & 0.118 & 0.473 & 0.552 & 0.974 & 1.43 \\
\hline S19 & 56.5 & 27.8 & 0.034 & 0.136 & 0.153 & 0.197 & 0.434 \\
\hline S20 & 61.2 & 30.4 & 0.037 & 0.149 & 0.165 & 0.212 & 0.474 \\
\hline S21 & 61.7 & 30.1 & 0.037 & 0.148 & 0.167 & 0.214 & 0.470 \\
\hline S22 & 54.7 & 27.0 & 0.033 & 0.132 & 0.148 & 0.192 & 0.420 \\
\hline S23 & 65.8 & 32.4 & 0.040 & 0.159 & 0.178 & 0.230 & 0.505 \\
\hline S24 & 50.0 & 24.2 & 0.030 & 0.119 & 0.135 & 0.182 & 0.376 \\
\hline S25 & 70.0 & 34.5 & 0.042 & 0.169 & 0.189 & 0.247 & 0.537 \\
\hline S26 & 31.6 & 15.4 & 0.019 & 0.076 & 0.085 & 0.112 & 0.240 \\
\hline S27 & 42.4 & 20.8 & 0.025 & 0.102 & 0.115 & 0.159 & 0.321 \\
\hline S28 & 43.1 & 20.9 & 0.026 & 0.103 & 0.116 & 0.156 & 0.324 \\
\hline S29 & 53.5 & 25.9 & 0.032 & 0.127 & 0.145 & 0.200 & 0.400 \\
\hline $\mathrm{S} 30$ & 53.8 & 26.6 & 0.033 & 0.130 & 0.145 & 0.185 & 0.415 \\
\hline S31 & 60.5 & 29.4 & 0.036 & 0.144 & 0.164 & 0.227 & 0.454 \\
\hline S32 & 64.9 & 31.9 & 0.039 & 0.156 & 0.175 & 0.231 & 0.496 \\
\hline S33 & 64.2 & 31.8 & 0.039 & 0.156 & 0.173 & 0.211 & 0.499 \\
\hline S34 & 62.7 & 30.7 & 0.038 & 0.151 & 0.169 & 0.225 & 0.476 \\
\hline Min & 21.6 & 10.5 & 0.013 & 0.052 & 0.058 & 0.082 & 0.162 \\
\hline Max & 204 & 96.4 & 0.118 & 0.473 & 0.552 & 0.974 & 1.43 \\
\hline Average & 62.1 & 29.3 & 0.038 & 0.148 & 0.156 & 0.235 & 0.453 \\
\hline
\end{tabular}




\section{Annual Effective dose Equivalent (E)}

The annual effective dose equivalent (E) was calculated from the absorbed dose by applying the dose conversion factor of $0.7 \mathrm{~Sv} / \mathrm{Gy}$ with an occupancy factor of 0.2 for outdoor and occupancy factor of 0.8 for indoor [22]:

$$
\mathrm{E}_{\text {out }}=\mathrm{D}(\mathrm{nGy} / \mathrm{h}) \times 8760(\mathrm{~h} / \mathrm{y}) \times 0.7(\mathrm{~Sv} / \mathrm{Gy}) \times 10^{-6} \times 0.2
$$

Equation (4) simplifies into $\mathrm{E}_{\text {out }}=\mathrm{D} \times 1.226 \times 10^{-3}$ $(\mathrm{mSv} / \mathrm{y})$

$$
\mathrm{E}_{\text {in }}=\mathrm{D}(\mathrm{nGy} / \mathrm{h}) \times 8760(\mathrm{~h} / \mathrm{y}) \times 0.7(\mathrm{~Sv} / \mathrm{Gy}) \times 10^{-6} \times 0.8
$$

Equation (5) simplifies into $\mathrm{E}_{\text {in }}=\mathrm{D} \times 4.905 \times 10^{-3}$ $(\mathrm{mSv} / \mathrm{y})$

To estimate annual effective doses, account must be taken of (a) the conversion coefficient from absorbed dose in air to effective dose and (b) the indoor occupancy factor. The average numerical values of those parameters vary with the age of the population and the climate at the location considered. In the UNSCEAR report, the committee used $0.7 \mathrm{~Sv} / \mathrm{Gy}$ for the conversion coefficient from absorbed doses in the air to the effective dose received by adults and 0.8 for the indoor occupancy factor, i.e., the fraction of time spent indoors and outdoors is 0.8 and 0.2 , respectively [28]. The resulting worldwide average of the annual effective dose is $0.48 \mathrm{mSv}$, with the results for individual countries being generally within the range of 0.3-0.6 mSv. For children and infants, the values are about $10 \%$ and $30 \%$ higher in direct proportion to an increase in the value of the conversion coefficient from absorbed doses in air to effective doses [22].

As shown in Table 4, the annual effective dose rate for the outdoors ranged between $0.013-0.118 \mathrm{mSv} / \mathrm{y}$ with a mean value of $0.038 \mathrm{mSv} / \mathrm{y}$, while the annual effective dose rate for indoors ranged between $0.052-0.743 \mathrm{mSv} / \mathrm{y}$ with a mean value of $0.148 \mathrm{mSv} / \mathrm{y}$. The corresponding world average value is $0.48 \mathrm{mSv} / \mathrm{y}$, of which $0.07 \mathrm{mSv} / \mathrm{y}$ is from outdoor and $0.41 \mathrm{mSv} / \mathrm{y}$ from indoor exposure [22]. Therefore, the study area is still in the zones of normal radiation levels, which can be considered as less of a threat to the environment as well as human health. The variations of the average values of radium equivalent $\left(\mathrm{Ra}_{\mathrm{eq}}\right)$, absorbed dose rate (D), annual effective dose for outdoor $\mathrm{E}_{\text {out }}$, and annual effective dose for indoor $\mathrm{E}_{\text {in }}$ in the different locations are due to the distributions of radionuclides in soil samples.

\section{External and Internal Hazard Indices $(H)$}

The external exposure to gamma rays in the study area is called external hazard index, or $\mathrm{H}_{\mathrm{ex}}$. This index is given by the following equation [20]:

$$
\mathrm{H}_{\mathrm{ex}}=\mathrm{A}_{\mathrm{Ra}} / 370+\mathrm{A}_{\mathrm{Th}} / 259+\mathrm{A}_{\mathrm{K}} / 4810 \leq 1
$$

In addition to $\mathrm{H}_{\mathrm{ex}}$, internal exposure to radon and its short-lived products are also hazardous to the respiratory organs. The internal exposure to radon and its daughter products is quantified by the internal hazard index $\left(\mathrm{H}_{\mathrm{in}}\right)$, which is given by the following equation [22]:

$$
\mathrm{H}_{\text {in }}=\mathrm{A}_{\mathrm{Ra}} / 185+\mathrm{A}_{\mathrm{Th}} / 259+\mathrm{A}_{\mathrm{K}} / 4810 \leq 1
$$

...where $\mathrm{A}_{\mathrm{K}}, \mathrm{A}_{\mathrm{Ra}}$, and $\mathrm{A}_{\mathrm{Th}}$ are the activity concentrations $\left((\mathrm{Bq} / \mathrm{kg})\right.$ of the specific radiation) of ${ }^{226} \mathrm{Ra},{ }^{232} \mathrm{Th}$, and ${ }^{40} \mathrm{~K}$, respectively. The maximum value of $\mathrm{H}_{\mathrm{ex}}$ was found to be less than unity corresponds to the upper limit of $\mathrm{Ra}_{\mathrm{eq}}(370 \mathrm{~Bq} / \mathrm{kg})$. If the maximum concentration of radium is half that of the normal acceptable limit then $\mathrm{H}_{\text {in }}$ will be less than 1. The prime objective of this index is to limit the radiation dose to dose equivalent limit of $1 \mathrm{mSv} / \mathrm{y}$ [27]. Gamma Index deals with the assessment of excess gamma radiation originating from the present soil. The calculated values of $\mathrm{H}_{\text {in }}$ are ranged from 0.082 to 0.974 with an average of 0.235 , which is lower than the recommended limit. $\mathrm{H}_{\mathrm{ex}}$ values vary from 0.058 to 0.552 with a mean value of 0.156 , and all values are less than the critical value of unity. As shown in Table 4, the internal hazard index is greater than the external hazard index at all sampling sites.

\section{Representative Level Index (I $)$}

The level of gamma radiation hazard due to the specified radionuclides of ${ }^{226} \mathrm{Ra},{ }^{232} \mathrm{Th}$, and ${ }^{40} \mathrm{~K}$ were assessed by another index called representative level index, or $\mathrm{I}_{\gamma \mathrm{r}}$. The representative level index, $\mathrm{I}_{\gamma \mathrm{r}}$, must be less than unity to keep the radiation hazard insignificant for the public. The following equation was applied to calculate $I_{\gamma \mathrm{r}}$ for soil samples under investigation [29]:

$$
\mathrm{I}_{\gamma \mathrm{r}}=\mathrm{A}_{\mathrm{Ra}} / 150+\mathrm{A}_{\mathrm{Th}} / 100+\mathrm{A}_{\mathrm{K}} / 1500 \leq 1
$$

...where $A_{R a}, A_{T h}$, and $A_{K}$ are the specific activities of ${ }^{226} \mathrm{Ra}$, ${ }^{232} \mathrm{Th}$, and ${ }^{40} \mathrm{~K}$ in $\mathrm{Bq} / \mathrm{kg}$, respectively. $\mathrm{I}_{\gamma \mathrm{r}}$ varies from 0.162 to 1.43 , with a mean value of 0.453 as shown in Table 3 . The values of representative level index for all soil samples were lower than unity, with the exception of the sample from site No. 18. However, the average value of representative level index $\left(\mathrm{I}_{\gamma \mathrm{r}}\right)$ is less than unity.

\section{Conclusions}

In the present study, the activity concentrations for ${ }^{238} \mathrm{U},{ }^{226} \mathrm{Ra},{ }^{232} \mathrm{Th},{ }^{40} \mathrm{~K}$, and ${ }^{137} \mathrm{Cs}$ were measured in 34 soil samples collected from Ras Tanura city, Saudi Arabia, near an oil refinery and around a residential area using gamma-ray spectrometry. The measurements of all samples under investigation showed that the mean values of radioactivity levels were lower than the world average for ${ }^{238} \mathrm{U},{ }^{226} \mathrm{Ra},{ }^{232} \mathrm{Th},{ }^{40} \mathrm{~K}$ and ${ }^{137} \mathrm{Cs}$. The maximum value of ${ }^{226} \mathrm{Ra}$ in soil was $156 \pm 3.6 \mathrm{~Bq} / \mathrm{kg}$, 
which is higher than the recommended value. However, the mean values of radium equivalent activity $\left(\mathrm{Ra}_{\mathrm{eq}}\right)$, total absorbed dose rate in air $1 \mathrm{~m}$ above the ground (D), annual effective dose for outdoor $\mathrm{E}_{\text {out }}$, annual effective dose for indoor $\mathrm{E}_{\text {in }}$, internal hazard index $\left(\mathrm{H}_{\mathrm{in}}\right)$, and external hazard index $\mathrm{H}_{\mathrm{ex}}$ were found to be lower than the allowed limits recommended by the international agencies (UNSCEAR and ICRP). Based on these results of radium equivalent activity and radiation hazard indices, one can conclude that there is no radiological health hazard from the soil of Ras Tanura to the people living near a refinery area as far as gamma radioactivity is concerned.

A comparison of the results of the analyzed soil samples with those from other studies shows that the activity concentrations of ${ }^{238} \mathrm{U},{ }^{226} \mathrm{Ra},{ }^{232} \mathrm{Th},{ }^{40} \mathrm{~K}$, and ${ }^{137} \mathrm{Cs}$ were within the range in the literature.

This study is the first conducted on Ras Tanura soil. Therefore, the information gathered from this study will help get the information regarding the background radiation levels in the studied area and, very importantly, figure out the baseline data of the radioactivity levels in the Arabian Gulf region.

\section{Acknowledgements}

The authors would like to thank Ameena Alahmari from the research units laboratory at Imam Abdulrahman Bin Faisal University for helping in gamma-ray spectrometry measurements. Great thanks are extended to student Abdullah Alamri at Imam Abdulrahman Bin Faisal University for assistance.

\section{Conflict of Interest}

The authors declare no conflict of interest.

\section{References}

1. EL-TAHER A., MADKOUR H. Distribution and Environmental Impacts of Metals and Natural Radionuclides in Marine Sediments In Front of Different Wadies Mouth along the Egyptian Red Sea Coast. Applied Radiation and Isotopes, 69, 550, 2011.

2. MADKOUR H.A., EL-TAHER A., AHMED A.N., MOHAMED A.W., EL-ERIAN T.M. Contamination of coastal sediments in El-Hamrawein Harbour, Red Sea, Egypt. Journal of Environmental Science and Technology, 5 (4), 210, 2012.

3. RAHMAN S.U., MATIULLAH, MALIK F., RAFIQUE M., ANWAR J., ZIAFAT M., JABBAR A. Measurement of naturally occurring/fallout radioactive elements and assessment of annual effective dose in soil samples collected from four districts of the Punjab Province, Pakistan. Journal of Radioanalytical and Nuclear Chemistry, 287, 647, 2011.

4. MANSOUR N.A., AHMED T.S., FAYEZ-HASSAN M., HASSAN N.M., GOMAA M.A., ALI A. Measurements of Radiation Level around the Location of NORM in Solid Wastes at Petroleum Companies in Egypt. Journal of American Science, 8 (6), 252, 2012.

5. ROOD A.S. In: 29th Midyear Topical Meeting of the Health Physics Society, Scottsdale, Arizona, USA, January 7-10, 10, 1998.

6. GAZINEU M.H.P., DE ARAUJO A.A., BRANDAO Y.B., HAZIN C.A., DE O GODOY J.M. Radioactivity concentration in liquid and solid phases of scale and sludge generated in the petroleum industry. Journal of Environmental Radioactivity, 81,47, 2005.

7. SANTAWAMAITRE T., MALAIN D., AL-SULAITI H.A., MATTHEWS M., BRADLEY D.A., REGAN P.H. Study of natural radioactivity in riverbank soils along the Chao Phraya river basin in Thailand. Nuclear Instruments and Methods in Physics Research A, 652, 920, 2011.

8. HAMZAH Z., ABDUL RAHMAN S.A., SAAT A. Measurement of ${ }^{226} \mathrm{Ra},{ }^{228} \mathrm{Ra}$ and ${ }^{40} \mathrm{~K}$ in soil in district of Kuala Krai, using gamma spectrometry. Malaysian Journal of Analytical Sciences, 15 (2), 159, 2011.

9. OBHOXAS J., VALKOVIC V., MATJACIC L., NAX K., SUDAC D. Evaluation of elemental composition of sediments from the Adriatic Sea by using EDXRF technique. Applied Radiation and Isotopes, 70 (7), 1392, 2012.

10. CHAD-UMOREN Y.E., OHWEKEVWO E. Influence of Crude Oil Spillage on the $\gamma$-Radiation Status of Water and Soil in Ogba/Egbema/Ndoni Area, Nigeria. Energy and Environment Research, 3(2) 45, 2013.

11. ABO-ELMAGD M., SOLIMAN H.A., SALMAN KHA., EL-MASRY N.M., Radiological hazards of TENORM in the wasted petroleum pipes. Journal of Environmental Radioactivity, 101, 51, 2010.

12. GAZINEU M.H.P., HAZIN C.A. Radium and potassium-40 in solid wastes from the oil industry. Applied Radiation and Isotopes, 66, 90, 2008.

13. AL ATTAR L., DOUBAL W., AL ABDULLAH J., KHALILY H., ABDUL GHANI B., SAFIA B. Characterization of NORM solid waste produced from the petroleum industry. Environmental Technology, 36 (9) 1104, 2015.

14. AKHTAR N., TUFAIL M. Cancer risk in Pakistan due to natural environmental pollutants. International Journal of Environmental Research, 5 (1), 159, 2011.

15. EL-TAHER A. Gamma spectroscopic analysis and associated radiation hazards of building materials used in Egypt. Radiation Protection Dosimetry, 138 (2), 158, 2010a.

16. EL-TAHER A. Determination of Chromium and Trace Elements in El-Rubshi Chromite from Eastern Desert Egypt by Neutron Activation Analysis. Applied Radiation and Isotopes, 68, 1864, 2010b.

17. EL-TAHER A. Elemental Content of Feldspar from Eastern Desert, Egypt, determined by INAA and XRF. Applied Radiation and Isotopes, 68, 1185, 2010c.

18. UNSCEAR. Exposures of the public and workers from various sources of Radiation. Report to the general assembly. Annex B, 2008.

19. ALSHAHRI F., ALQAHTANI M. Chemical fertilizers as a source of ${ }^{238} \mathrm{U},{ }^{40} \mathrm{~K},{ }^{226} \mathrm{Ra},{ }^{222} \mathrm{Rn}$ and trace metal pollutant of the environment in Saudi Arabia. Environmental Science and Pollution Research, 22, 8339, 2015.

20. ALZAHRANI J.H., ALHARBI W.R., ABBADY A.G.E. Radiological impacts of natural radioactivity and heat generation by radioactive decay of phosphorite deposits 
from Northwestern Saudi Arabia. Australian Journal of Basic and Applied Sciences, 5 (6), 683, 2011.

21. CURRIE L.A. Limits for qualitative detection and quantitative determination application to radiochemistry. Analytical Chemistry, 40, 586, 1989.

22. UNSCEAR. United Nations Scientific Committee on the Effects of Atomic Radiation. Sources and Effects of Ionizing Radiation. Report to the General Assembly, Annex A \& B, I, 20, 2000.

23. JIBIRI N.N., AMAKOM C.M. Radiological Assessment of Radionuclide Contents in Soil Waste Streams from an Oil Production Well of a Petroleum Development Company in Warri, Niger Delta, Nigeria. Indoor and Built Environment, 20 (2), 246, 2011.

24. AL ABDULLAH J., AL-MASRI M.S., AMIN Y., AWAD I., SHEAIB Z. Chemical fractionation of radium-226 in NORM contaminated soil from oilfields. Journal of Environmental Radioactivity, 165, 47, 2016.

25. AJAYI T.R., TORTO N., TCHOKOSSA P., AKINLUA A. Natural radioactivity and trace metals in crude oils: implication for health. Environmental Geochemistry and Health, 31, 61, 2009.

26. ALASHRAH S., EL-TAHER A. Assessment of natural radioactivity level and radiation hazards in soil samples of Wadi Al- Rummah Qassim province, Saudi Arabia. Journal of Environmental Biology, 37, 985, 2016.

27. ICRP. International Commission on Radiological Protection, ICRP 65:Protection Against Radon-222 at Home and at Work, ICRP 23. Pergamon Press, Oxford, 1993.

28. UNSCEAR. United Nations Scientific Committee on the Effects of Atomic Radiation. Sources and effects of ionizing radiation. Report to the General Assembly, with Scientific Annexes, 1993.

29. RAVISANKAR R., CHANDRAMOHAN J., CHANDRASEKARAN A., JEBAKUMAR J.P.P., VIJAYALAKSHMI I, VIJAYAGOPAL P., VENKATRAMAN B. Assessments of radioactivity concentration of natural radionuclides and radiological hazard indices in sediment samples from the East coast of Tamilnadu, India with statistical approach. Marine Pollution Bulletin, 97, 419, 2015.

30. SONG G., CHEN D., TANG Z., ZHANG Z., XIE W. Natural radioactivity levels in topsoil from the Pearl River Delta Zone, Guangdong, China. Journal of Environmental Radioactivity, 103, 48, 2012.

31. IDRISS H., SALIH I., ALAAMER A.S., SALEH A., ABDELGALI M.Y. Environmental-Impact Assessment of Natural Radioactivity Around a Traditional Mining Area in Al-Ibedia, Sudan. Archives of Environmental Contamination and Toxicology, 70, 783, 2016.

32. SALEH H., ABU SHAYEB M. Natural radioactivity distribution of southern part of Jordan (Ma'an) Soil. Annals of Nuclear Energy, 65, 184, 2014.
33. PAPP Z. Natural radioactivity in the soils of some eastern counties of Hungary. Radiation Protection Dosimetry, 141 (1) $56,2010$.

34. EL-GAMAL E., FARID M.E., ABDEL MAGEED A.I., HASABELNABY M., HASSANIEN H.M. Assessment of natural radioactivity levels in soil samples from some areas in Assiut, Egypt. Environmental Science and Pollution Research, 20, 8700, 2013.

35. BAOZHU L.I., YONGFENG Y.A.N. A study of natural radioactivity levels of soil in the Lincang Basin, Yunnan. Chinese Journal of Geochemistry, 31, 191, 2012.

36. TUFAIL M., ASGHAR M., AKRAM M., JAVIED S., KHAN K., MUJAHID S.A. Measurement of natural radioactivity in soil from Peshawar basin of Pakistan. Journal of Radioanalytical and Nuclear Chemistry, 298, 1085, 2013.

37. AGBALAGBA E.O., ONOJA R.A. Evaluation of natural radioactivity in soil, sediment and water samples of Niger Delta (Biseni) flood plain lakes, Nigeria. Journal of Environmental Radioactivity, 102 (7), 667, 2011.

38. ABD EL-MAGEED A., EL-KAMEL A., ABBADY A., HARB S., YOUSSEF A., SALEH I. Assessment of natural and anthropogenic radioactivity levels in rocks and soils in the environments of Juban town in Yemen. Radiation Physics and Chemistry, 80, 710, 2011.

39. BOUKHENFOUF W., BOUCENNA A. The radioactivity measurements in soils and fertilizers using gamma spectrometry technique. Journal of Environmental Radioactivity, 102, 336, 2011.

40. AKÖZCAN S. Natural and artificial radioactivity levels and hazards of soils in the Kücük Menderes Basin, Turkey. Environmental Earth Sciences, 71 (10), 4611, 2014.

41. KOLO M.T., ABDUL AZIZ S.A.B., KHANDAKER M.U., ASADUZZAMAN K., AMIN Y.M. Evaluation of radiological risks due to natural radioactivity around Lynas Advanced Material Plant environment, Kuantan, Pahang, Malaysia. Environmental Science and Pollution Research, 22, 13127, 2015.

42. BANGOTRA P., MEHRA R., KAUR K., JAKHU R. Study of natural radioactivity $\left({ }^{226} \mathrm{Ra},{ }^{232} \mathrm{Th}\right.$ and $\left.{ }^{40} \mathrm{~K}\right)$ in soil samples for the assessment of average effective dose and radiation hazards. Radiation Protection Dosimetry, 171 (2), 277, 2016.

43. MOHAMMED R.S., AHMED R.S. Estimation of excess lifetime cancer risk and radiation hazard indices in southern Iraq. Environmental Earth Sciences, 76, 303, 2017.

44. AL-ZAHRANI J.H. Radioactivity measurements and radiation dose assessments in soil of Albaha Region (Saudi Arabia). Life Science Journal, 9, 2391, 2012.

45. ALAAMER A.S. Assessment of Human Exposures to Natural Sources of Radiation in Soil of Riyadh, Saudi Arabia. Turkish Journal of Engineering and Environmental Sciences, 32, 229, 2008. 